\title{
International Cooperation on Law against Terrorism: The Harmonization of Antiterror Laws of Turkey and Macedonia
}

\author{
Dr. Fehmi Agca \\ International Balkan University \\ Dr. Nicola Dacev \\ International Balkan University
}

\begin{abstract}
The number of terrorist attacks has been steadily increasing in the past decade. Also, the number of countries exposed to the threat of terrorism is increasing. Terrorism is getting more momentum and wider proportions. Most countries have adopted new legal provisions against the terrorism. The new technologies enable terrorist groups to attract new members, to develop new techniques, to transfer money for financing terrorism, to reach easier worldwide communication and movement between countries. Taking into account the extent of terrorism, the new anti-terrorism legislation is necessary for the prevention of terrorist attacks in future. But, at the final stage, the success of the new legal framework will depend on the international cooperation and good faith and honesty of the global powers. The aim of this article is to review the anti-terror legislations in Turkey and Macedonia, UN Security Council resolutions and EU conventions related to terrorism. In this context, a comparative method of legal research is used to determine the applicability of the existing legislation that regulates this issue.
\end{abstract}

Keywords: Anti-terror laws, Terrorism, Technology, Financing Terrorism, International Cooperation.

\section{INTRODUCTION}

The world has experienced a dramatic event at the beginning of the $21^{\text {st }}$ century. The $9 / 11$ attack in New York has fundamentally shaken the international relations, alliances and strategic notions. In this context, threat and security concepts have changed to a great extent.Parallel to the rapid changes in the post-Cold War era, the new risks and threats represented a wide spectrum regarding their characteristics. These asymmetric threats, particularly international terrorism, use technology increasingly and restructuring themselves at the international level.

In today's chaotic environment, the societies demand much better service from security forces. Therefore, the ability 
of thinking and acting proactively have gained greater importance for the sustainable success of the security forces. Combating against the international terrorism is one of the major challenges for the international community. Although the enforcement of the law is the responsibility of the sovereign nations, a coordinated international response and a close regional cooperation are vital for the success of the anti-terror policies. At the national level, it is essential to take necessary protective measures to ensure the security of the people. Terrorism is the enemy of the democracy. In this context, to maintain the balance between democratic values and public demand for strict measures against terrorism is crucial. At the international level, nations should agree on a clear definition of terrorism. Without a consensus on the definition and understanding of terrorism, it will not be possible to win this struggle.

The UN General Assembly couldn't have reached the consensus on a definition of terrorism that is acceptable by all states. Different approaches to the definition make it difficult to pass a comprehensive convention on terrorism that criminalizes all forms of terrorism. Discussion among the legal experts at the UN has not concluded with a clear understanding of the meaning of terrorism. The lack of definition is creating difficulty to reach agreements on common actions by the international community.An international military coalition force cannot successfully fight without agreeing on who the enemy is. (Lindberg, 2010)

International cooperation is prerequisite in fighting against terrorism.Today's global counter-terrorism framework includes UN conventions and protocols, Security Council resolutions, the UN Global Counter-terrorism Strategy, and some regional instruments. The 16 conventions and protocols of the UN constitute the normative and legal basis of the global counter-terror efforts. At the global level of fighting against terrorism, the Office of the UN Counter-Terrorism Implementation Task Force, co-sponsored by Switzerland, Germany, Norway, Austria, Turkey as well as the US, organized regional conferences between 2010 and 2012. The aim

Inquiry Global Counter-Terrorism Strategy.

2016/1

\section{TURKEY`S ANTI-TERROR LAWS}

For the last thirty years, Turkey has been targeted by the separatist terrorist organization PKK. Since 1984, more than thirty thousand people were killed or injured because of the terrorist attacks. Turkey has managed to execute effective and successful fighting against the terrorists inside and outside the country. In fighting terrorism, Turkey has fully respected to the democratic values and and fundamental human rights. In the light of UN conventions and EU regulations, Turkish parliament modified the 
anti-terror laws taking into account the changing requirements of the its counter-terrorism strategy.

The Law on Fight against Terrorism of Turkey' adopted in 1991 establishes three main criteria for defining a terrorist act: First, it concerns the use of coercion, violence, terror, intimidation or threats. Second, the terrorist action needs to be designed to impair the basic characteristics of the Republic specified in the Constitution, or the country's political, legal, secular and economic systems, violate territorial or national integrity, and jeopardize the existence of Turkey, weaken government authority, destroy fundamental rights and freedoms, impair the domestic and international security, public order or public health.Third, the person or persons who committed an act must belong to an organization. (The Law on Fight against Terrorism of Turkey, 1991)

Turkey is committed to combating terrorism without discrimination and takes influential measures against associating terrorism with any religion, nationality, civilization or ethnic group. Based on its national experience, and in line with the UN CounterTerrorism Strategy, Turkey adopted human rights based, multidimensional counter-terrorism practices, with full respect for the rule of law. In this context, Turkey tries to keep the balance between security measures and fundamental rights in a democratic system.

An effective coordination among different responsible bodies is crucial for a successful counter-terrorism strategy. In this regard, the Under-Secretariat for Public Order and Security established in 2010, has developed measures to combat terrorism, by evaluating strategic intelligence. It also acknowledged the people to gain the public support and trust in counter-terrorism efforts. Relying only on security measures does not produce a sustainable solution to the threat of terrorism. Thus, Turkey had a paradigm shift in its counter -terrorism strategy. The most important one is the democratic opening process. In this process, Turkey adopted a holistic concept comprising political, cultural, social and economic dimensions, as well as international cooperation. But, this process ended because of the Syrian Crises and the manipulation of the separatist terrorists by some global powers.

'The Law on the Prevention of Financing of Terrorism ' came into effect on 16 February 2013. This law provides the principles and procedures in the implementation of the UN Security Council Resolutions, through the decision of the Council of Ministers. In the case of a request made by a another state to Turkey to freeze the assets of a person or organization, the Council of Ministers will make a decision after getting the assessment of the Commission. The Commission may also propose to the Council of Ministers to request freezing of the assets of persons, institutions or 
organizations in foreign countries, because of financingterrorist acts (The Law on the Prevention of Financing of Terrorism of Turkey, 2013). It is obvious that the effectivedetection of terrorist activities could be accomplished when the governmet authorities assess the intelligence about terrorists and financial information together. The success of the investigation will depend on the sincere sharing of the information by the states and international organizations. (Best, 2001)

'The Law on Witness Protection' envisages principles and procedures regarding the protection of witnesses at risk in criminal proceedings. The witnesses in criminal proceedings for the offenses requiring a sentence from 10 years to life can benefit from protective measures (The Law on Witness Protection of Turkey, 2007). In practice, the secret witnessing under the protection of this legal provision caused unfair decisions by some judges. A fair hearing cannot be set without cross-questioning. This law actually was used to blame the persons who were not guilty by manipulating the realities. In this regard, many innocent individuals have suffered because of the impartial decisions of the courts.

Turkey has actively supportedthe international efforts for cooperation inrestricting terrorists from reaching safe heavens, to improve border and customs controls, and to bring the perpetrators to justice for extraditing or prosecuting. In addition, Turkey exchanges information concerning the prevention and combating terrorism, without delay. It is important to remember that Turkey warned the Belgium and Netherland government authorities before the terrorist attacks in Brussel on 22 March 2016. Unfortunately, they ignored the Turkey's warning. Belgium has also rejected Turkey's requests many times to send back the criminal individuals to Turkey. Because of the negative approach by some EU member states, European cities have now become a safe haven for the terrorists. Turkey considers UN conventions and protocols,Security Council Resolutions and the Council of Europe decisions on terrorism as a legal basis and a road map to combat terrorism. In this context, Turkey has fully co-operated with the UN CounterTerrorism Committee and regularly submitted its country reports.

Turkey still contributes to capacity building efforts of the UN agencies and regional organizations as well as conducting extensive bilateral capacity building programs. Further, Turkey signed bilateral agreements with many countries on cooperation in combating terrorism, organized crime, and drug trafficking. Turkey is party to the European Convention on Mutual Assistance in Criminal Matters and European Convention on Extradition. One of the major difficulties encountered is the refusal to extradite the terrorists claiming that the offense in question is of a political nature.

It is important to give careful consideration to the difference 
between a political offense and a terrorist crime. The UN Security Council Resolution 1373 states: "Claims of political motivation are not recognized as grounds for refusing requests for the extradition of alleged terrorists" (UN Security Council Resolution 1373, 2001). The main obligation of the States relating to terrorism is to bring perpetrators to justice either through extradition or prosecution before national courts. Abuse of the refugee status is a major problem in this struggle. Some European states refuse to cooperate in the prosecution or extradition of some terrorists. For example, Belgium rejected to send back a murderer to Turkey and provided safety and freedom of movement to this terrorist without a reasonable explanation. Many European states continue to support the separatist PKK terrorist organization members in their countries although they have declared that the PKK is a terrorist organization.

\section{ANTI-TERROR LAWS OF MACEDONIA}

The Republic of Macedonia, like other countries, is not immune to terrorism. A terrorist action happened in the days of 9 and 10 May 2015, in the city of Kumanovo neighborhood "Divo naselje". During the fighting against the armed terrorist group, eight members of the special unit of the Macedonian police were killed, and 37 police officers were injured. 14 terrorists were killed, and about 30 members of the terrorist group surrendered to the police. Macedonia faces a serious challenge to maintain the security and stability of the country.

The term terrorism in Macedonian laws was first mentioned and regulated with a large number of legal provisions in the Criminal Code dated 1996. It prescribes penalties for terrorists endangering of the constitutional system and security, criminal association, the terrorist organization, financing terrorism and international terrorism (Criminal Code of Macedonia, 1996).

It is realistic to expect that Macedonia cannot answer alone to all kinds of contemporary security threats, such as modern terrorism, organized crime, trafficking in drugs, human, weapons, which are transnational in nature. Therefore, several laws were enacted to regulate the international cooperation of Macedonia with other countries regarding criminal matters, covering the fight against terrorism.

According to the 'Law on International Cooperation in Criminal Matters' dated 2010, Macedonia provides international cooperation in all proceedings related to criminal acts. Furthermore, international cooperation is given in proceedings before the European Court of Human Rights, the European Court of Justice, the International Criminal Court, and other international 
organizations when an international agreement requires the cooperation. International cooperation in criminal matters includes international legal assistance, criminal prosecution, extradition and enforcement of criminal judgments and the transfer of sentenced persons (Law on International Cooperation in Criminal Matters of the Macedonia, 2010).

'Law on Witness Protection' of Macedonia dated 2005 applies if the proving of the crime cannot be conducted without the statement of a person who disagrees as a witness to testify for offenses against the state, humanity and international law under the threat of revenge or danger to life, health, freedom, physical integrity or property and for the offenses that the Criminal Code stipulates a prison sentence of at least four years (Law on Witness Protection of Macedonia, 2005).

To set out the measures for detecting and preventing money laundering, as a process of concealing the origin of financial assets and transfer into legal financial system; and financing of terrorism, as a process of gathering and distributing of these assets; Macedonia adopted the 'Law on Prevention of Money Laundering and Financing of Terrorism in 2014. The article 89 of the law states that the Financial Intelligence Office may conclude agreements for cooperation with other countries and international organizations in the fight against money laundering and financing of terrorism ( Law on Prevention of Money Laundering and Financing of Terrorism of Macedonia, 2014).

Macedonia harmonized the Law on Prevention of Money Laundering and Financing of Terrorism with the international conventions, directives and recommendations, such as UN Convention against Transnational Organized Crime, International Convention for the Suppression of the Financing of Terrorism, and EU Council Directive on the Prevention of the Use of the Financial System for the Purpose of Money Laundering and Terrorist Financing (EC Decision, 2005/60). Macedonia also signed some bilateral agreements, with Albania in 2005, with Bosnia and Herzegovina in 2009, with Romania in 2004 and Poland in 2008 Inquiry on Cooperation in Combating Terrorism, Organized Crime, Illicit 2016/1 Trafficking in Narcotic Drugs.

In 2014 , to identify the causes and prevent violent radicalism and extremism, Macedonia started the project "Prevention of violent extremism and radicalization that lead to terrorism through community policing." Within this project, 150 trainers assisted police officers to detect possible signs of extremism that can lead to terrorism. In Macedonia, it is necessary to work on improving the legislation that may prevent the terrorism. But, if the financial support for the terrorist organizations continues, prevention of terrorist attacks will be carried out with difficulty, despite the existence of legal capacity. 
The central position of the Macedonia in the Balkans geography makes the country a transition corridor for the organized crime and terrorist activities. The harmonization of the Macedonian antiterror laws in line with the UN conventions and EU regulations is expected to contribute to the fighting against terrorism in the Balkans. At this stage, with the help of EU, Macedonia needs to increase its institutional and operational capacity of the security forces.

\section{THE LACK OF INTERNATIONAL COOPERATION ON THE FIGHT AGAINST TERRORISM}

After the September 11 terrorist attacks in New York, the normative framework against global terrorism has been significantly strengthened. Today there is a wide range of legal legislation in the world related to anti-terrorism, suchas international conventions, UN Security Council resolutions, regional agreements, and EUantiterrorist legislation.The UN Security Council has strengthened the international legal foundation for counter-terrorism efforts by issuing numerous binding resolutions. The UN alsoadopted the Global Counter-Terrorism Strategy that contains practical recommendations for tackling, preventing and combating terrorism and ensuring respect for human rights. Because of different threat perceptions, only a few number of countries ratified 16 conventions and protocols until today. Some states perceive terrorism as a lesser priority in the light of other challenges.

The struggle against terrorism requires that the states do not sponsor or aid transnational terrorism and take responsibility for the welfare of the citizens and reduce the possibility of terrorist acts. The powerful states have the responsibility to assist weak states. Otherwise, fostering the capabilities of the states to fight against terrorism cannot be possible. Furthermore, the number of the failed states will increase and the chaos will spread throughout the world. An effective legal structure for counter-terrorism requires a potent law enforcement, intelligence gathering, and strict security measures to be conducted by the states. Bilateral efforts may have a critical affect for building effective institutions and capable personnel. The combination of national efforts and international cooperation in fighting terrorism have shown that it is possible to defeat and deter such movements and threats if the international actors honestly and actively cooperate with the unity of action (Cordesman and Burke,2010).

Today's legal framework against global terrorismrequires a central global body dedicated to terrorist prevention and response. Counter-terrorism effortsare multilayered ranging from legally binding instruments and strategic guidelines to multilateral 
institutions and regional frameworks. The existing conventions against terrorism provide a universal legal regime against terrorism. For today, the UN General Assembly has not reached the consensus on the definition of terrorism that would be accepted by all countries. The differences over the definition of terror have been a major factor in the failure to accept a comprehensive convention on terrorism that criminalizes all forms of international terrorism. Although there is considerable progress toward building a normative framework for terrorism since $9 / 11$, the national differences continue to obstruct efforts to build a comprehensive treaty that would unite all aspects of counter-terrorism under one legal framework (Council on Foreign Relations, 2013).

\section{CONCLUSION}

The cooperation among the nations can only be possible by recognizing and evaluating every kind of terrorist organization as a common threat without making any discrimination among them. The international community should have the same understanding of terrorism. Double standards in the fighting against terrorism might have extremely adverse results, even for the defenders of this approach. Supporting terrorism must not be a policy of national interest.

Terrorism is a common challenge that we need to resolve in solidarity. Whatever their motivations and objectives, terrorism can not be justified. It should be condemned by all the states. Any state shouldn't rely on its border security, self-defence power or its economic power. No nation can defeat terrorism alone. National defense and response capabilities are important to fight against terrorism, but not sufficient. In this sense, the international community should cooperate for the effective use of their military forces.In this context, human rights violations continue to be a significant challenge.International cooperation should focus to find the best ways to defeat terrorists with minimum violation of human rights. The life of ordinary citizens in any country must be under the guarantee of the rule of law.

Terrorism may occur in any country, whether it is developed or underdeveloped, democratic or authoritarian. Thus, there is no single cause of terrorism or a common set of causes. It is highly difficult to exterminate the sources of terrorism completely. The international community should find concrete remedies to solve the deepening structural problems between wealthy and poor countries. Terrorism has no religion, nationality or culture and not confined to a particular region. Terrorist attacks in many parts of the world remind us this reality. Terrorism is a major violation of the most fundamental human rights: the right to live. By creating a climate of fear, terrorism violates every individual's right to live free from fear. 
The fight against terrorism requires a unified, determined and coordinated response from the national authorities as well as the international community. In this framework, it is necessary to establish new structures ensuring informational and intelligence sharing and a high-level contact among those structures. Without the active involvement of the five permanent members of the UN Security Council, an effective strategy against terrorism seems impossible. Full compliance with the provisions of the international conventions and UN Security Council resolutions is vital in the struggle against terrorism.

\section{REFERENCES}

Best, Richard A.(2001). Intelligence and Law Enforcement: Countering Transnati onal Threats to the US, Congressional Research Service, 3 Dec. 2001.

Cordesman, Anthony H. And Burke, Arleigh A.(2010). International Cooperation in Counterterrorism: Redefining the Threat and the Requirement, Center for Strategic and International Studies.

Council on Foreign Relations. (2013). 'The Global Regime for Terrorism ',Wash ingtonDC,website:http://www.cfr.org/terrorism/global-regimeterrorism

Criminal Code of Macedonia (1996). Official Gazette of the Republic of Macedonia, No.37/1996

Lindberg Miryam (2010). Impediments to International Cooperation Against Ter rorism, Análisis no 7954.

The Law on International Cooperation in Criminal Matters (2010). Official Gazette of the Republic of Macedonia, No.124/2010

The Law on Prevention of Money Laundering and Financing of Terrorism (2014). Official Gazette of the Republic of Macedonia, No.130/2014

The Law on Witness Protection,Official Gazette of the Republic of Macedonia, No.38/2005

The Law on Fight against Terrorism of Turkey (1991). Official Gazette of the Re public of Turkey.

https://www.imolin.org/doc/amlid/Turkey/Turkey_Anti-Terror_ Law_1991.pdf (12 May 2016)

The Law on Prevention of Financing of Terrorism of Turkey (2013). Official Gazette of the Republic of Turkey.

http://www.masak.gov.tr/media/portals/masak2/files/en/Legislation/ Laws/TFLaw_Turkey.pdf (13 May 2016)

The Law on Witness Protection of Turkey (2007). Official Gazette of the Republic of Turkey.

http://www.resmigazete.gov.tr/main.aspx?home=http://www.resmigazete.gov.tr/ eskiler/2008/01/200801051.htm/20080105.htm\&main=http://www.resmigazete. gov.tr/eskiler/2008/01/20080105-1.htm (13 May 2016)

UN Security Council Resolution 1373 (2001).

http://www.un.org/en/sc/ctc/specialmeetings/2012/docs/UnitedNationsSecurity CouncilResolution1373(2001).pdf (11 May 2016) 